\title{
Solid transformation of litharge into laurionite and blixite
}

\author{
L. KIRKES ${ }^{* 1}$, L. ZHANG ${ }^{1}$, Y.XIONG ${ }^{2}$, J. KNOX ${ }^{1}$,
} H. BURTON

${ }^{1}$ Sandia National Laboratories, 4100 National Parks Hwy, Carlsbad, NM 88220, USA (*correspondance

lkirkes@sandia.gov) ${ }^{2}$ Sandia National Laboratories, 1515

Eubank Boulevard SE, Albuquerque, NM 87123

The solid transformation of litharge $(\mathrm{PbO})$ into lauruionite $(\mathrm{PbCl}(\mathrm{OH}))$ and blixite $\left(\mathrm{Pb}_{8} \mathrm{O}_{5}(\mathrm{OH})_{2} \mathrm{Cl}_{4}\right)$ was studied in a matrix of magnesium chloride $\mathrm{MgCl}_{2} \cdot 6 \mathrm{H}_{2} \mathrm{O}$ from 0.008 to $2.0 \mathrm{~mol} \cdot \mathrm{kg}^{-1}$ and equal concentration of 0.042 mol $\cdot \mathrm{kg}^{-1}$ EDTA $\left.\left(\left(\mathrm{CH}_{2} \mathrm{COO}\right)_{2} \mathrm{~N}\left(\mathrm{CH}_{2}\right)_{2} \mathrm{~N}\left(\mathrm{CH}_{2} \mathrm{COO}\right)_{2}\right)^{4-}\right)$ in all samples. Litharge was used as the starting solid for the experiments. Solid and solution chemistry analyses were completed throughout the experiments. Experiments were conducted at ambient laboratory temperature and pressure, with insitu solution temperatures ranging from $21.08-21.84^{\circ} \mathrm{C}$ and insitu $\mathrm{pH}$ ranging from 8.00-11.86. XRD data in the figure below is representative of 3936 days.

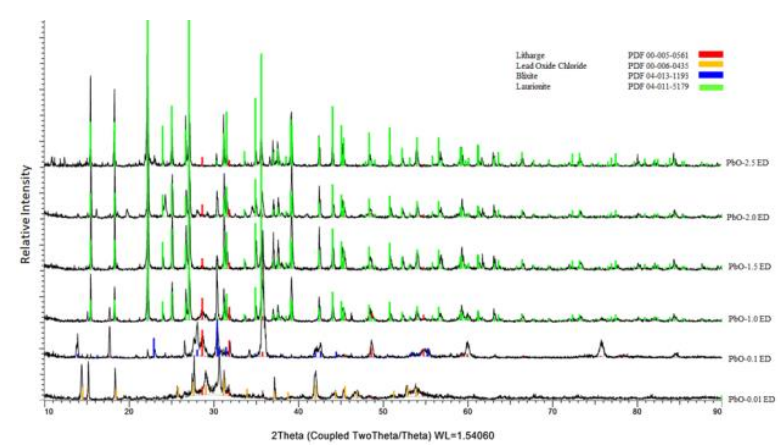

SEM/EDS analysis showed crystalline laurionite in 0.8-2.0 mol $\cdot \mathrm{kg}^{-1} \mathrm{MgCl}_{2} \cdot 6 \mathrm{H}_{2} \mathrm{O}$ matrices with a minimal presence of other solids. Litharge and blixite were visualized at lower ionic strengths, indicating a gradual solid transformation to laurionite with increasing $\mathrm{Cl}^{-}$concentration. The Pitzer model was used to predict the formation of laurionite and blixite at the experimental conditions.

Sandia National Laboratories is a multi-mission laboratory managed and operated by National Technology and Engineering Solutions of Sandia LLC, a wholly owned subsidiary of Honeywell International Inc. for the U.S.

Department of Energy's National Nuclear Security Administration under contract DE-NA0003525. This research is funded by the WIPP programs administered by the Office of Environmental Management (EM) of the U.S. Department of Energy. SAND2020-0549A 